\title{
Investigating features of Potato (Solanum tuberosum. var Mafrona) under usage of Biologic Manures Super Nitro plus \& Humic Acid ${ }^{1}$
}

\author{
Seyed Reza Miralizade Fard \\ Lecturer in Agriculture Department of Payamenoor University PO Box 19395-3697, Tehran, Iran. \\ http://dx.doi.org/10.13005/bbra/2021
}

(Received: 13 January 2016; accepted: 26 February 2016)

\begin{abstract}
To investigate the effect of biologic manures Super Nitro plus \& Humic acid on quantitative \& qualitative features of Solanum tuberosum var Mafrona, the test has been done as Factorial in the form of completely random block design with 3 replication in Dasht-e-Mir Farm sited $20 \mathrm{~km}$ far from Khodabandeh city with 36,03 longitude and 49,22 latitude during crop year 2014-15. Treatments include 3 levels of Humic acid 0, 2, 4 ( Liters per hectare) as foliar application after weeding bush \& super Nitro plus in 3 levels 0, 2, 4 ( Liters per hectare) as tuber impregnating with manure solution has been done. Results have indicated that Humic acid effect on studied features has been significant in $(\mathrm{P}<0.01)$ level and the highest yield and percentage of tuber dry matter from $4(\mathrm{~L} / \mathrm{ha})$ treatment has been obtained $31120(\mathrm{~kg} / \mathrm{ha})$ and $19.08(\mathrm{j})$, respectively. In investigating the interaction of Super Nitro plus and Humic acid in yield per unit area; 4 (L) biologic manure and 4 (L) Humic acid with $31740(\mathrm{~kg} / \mathrm{ha})$ value had the highest yield; also, the highest percentage of tuber dry matter has been obtained from 4 (L) Super Nitro plus treatment and 4 (L) Humic acid with 19.36 (j) value which is at the same statistical group with 2 (L) biologic manure and 4 (L) Humic acid with 19.13(j). Also, the highest percentage of Crude Protein (CP) has been obtained from 4 (L) Super Nitro plus treatment and 4 (L) Humic acid with 8.70 (j). the highest value of auxin hormone has been obtained from 2 (L) Humic acid treatment and 4 (L) biologic manure with 311.9 Micromole/g value.
\end{abstract}

Key words: Potato, biologic manure, Humic acid , IAA \& Marfona.

Potato (Solanum tuberosum) is one of important glandular crops which have a main and important role in world people nutrition and agricultural economy ${ }^{1}$. Potato is planted in most of world regions in range of $65^{\circ} \mathrm{N}$ to $45^{\circ} \mathrm{S}$ latitude and to a height of over 3500 meters from the sea level $^{2}$. Farmers try to make closer crop production to genetic power through resolving food deficiency \& using proper management operation ${ }^{3}$.Published Statistics by $\mathrm{FAO}^{4}$ (Food and Agriculture Organization) always indicate under plant growing trend and yield of this crop in Iran.

\footnotetext{
* To whom all correspondence should be addressed. Mob.: +989124821739

E-mail: m_t_a135970@yahoo.com
}

While plant grows in abnormal circumstances such as over-consumption of nitrogen manure; protein production decreases and nitrogen accumulate as non-protein form in the plant. Nitrate is one of the non-protein forms which its over-consumption will cause to toxicity in food chain $^{5}$. So, necessity of using different manure sources is increasing every day. One of the most important manure in consumption part of plant is Humic acid. Humic acid is a natural polymer related to $+\mathrm{H}$ acidic agents which has phenolic and benzoic Carboxyl positions (cation exchange locations). Humic acid can effect directly on plant growth ${ }^{6}$ have investigated the effect of humic acid on some grass. They have found that usage of humic acid result in increment of pasture plant shoot ${ }^{7}$ have investigated effect of humic acid on corn growth 
in calcareous soils in a greenhouse research. Their results have indicated that different dose of humic acid foliar application has different and significant effect on total dry weight value of plant and humic acid has positive and significant effect on absorption of Copper, Zinc, Manganese, Phosphorus, and Sodium in dose 0.01 .

In $^{8}$ research, different effects of humic acid on wheat have been investigated. Their results have investigated that different level of humic acid has different significances among stem weigh, height plant and value of nitrogen absorption in wheat growth.

Bulent Asik et.al (2012) ${ }^{9}$ have investigated effect of humic acid on type of Triticum durum Salihli .Their results have indicated that humic acid cause to increment in absorption of Phosphorus, Potassium, Magnesium, Sodium, Copper \& Zinc.

Usage of humic acid in the form of foliar application and soil in plant will cause to increment in Auxin, Cytokinin \& Gibberllins hormones ${ }^{10}$. In a research ${ }^{11}$, have investigated effect of humic acid on corn. Results of their investigation have indicated that humic acid can have very positive effect on plant physiology. Abu-aly \& Mady ${ }^{12}$ have reported that humic aid usage through shoot in wheat plant have caused to $3.1 \%$ auxin increment in shoot at 80 days after planting in two growing seasons.

Some of existent microorganisms in rhizosphere cause to physiologic and morphologic changes in plants due to different mechanisms; this series of changes affect plant growth, nutrition and health. Term "PGPR (Plant Growth Promoting Rhizobacteria)" has been presented at first by Kloeper , et al(13). Main plant growth motive bacteria which their applications in recent researches have been considered are related to azotobacter, azospirillum, pseudomonas \& Bacillus. Although, quality of plant relation and plant growth motive through this bacteria is not clarified completely; but their beneficial effects can be resulted from factors such as; antibiotics synthesis, siderophores, plant hormones, N2 biological consolidation, reduction in membranes electrical potential, production of some kind of enzymes such as ; Acc deaminase and increment in availability to nutrient elements (14). Piao et.al (15) have reported that due to inoculation of PGPRs, rice yield has increased in comparison to control group and inoculation of each strain . In fact, biologic manures are materials include different kind of free living microorganisms ${ }^{16-17}$, have the ability of converting main nutrient elements from unavailable form throughout biological processes $^{16 ; 18}$ and result in root system advancement and seed better germination ${ }^{17} ; 19$. Also, significance increment in seed yield and nitrogen accumulation in rice seed have been seen through insemination strain of Azospirillum amazonense with this plant ${ }^{20}$. It has been reported that Azospirillum bacteria not only produces growth motive hormones such as auxin and gibberellin but also releases hormones such as ABA (Abscisic acid) in tension ( stress) condition on order to decrease tension effect in the plant ; in fact , this bacteria cause to yield increment through growth promotion and tension decrement ${ }^{21-22}$. Also, Patten ${ }^{23}$ has reported increment in auxin production through Pseudomonas bacteria. Raja ${ }^{24}$ has investigated hormonic changes by Pseudomonas \& Azospirillum insemination through a research on rice seedling and has observed 9.6 \& 7.4 times auxin value in comparison to control treatment. Super Nitro plus manure include Bacillus subtilis, Pseudomonas fluorescens and Azospirillum spp. This biologic manure contains $10^{8}$ bacteria per milliliter.

\section{MATERIALSAND METHODS}

This research has been done as Factorial in the form of completely random block design with 3 repeat in Dash Mir Farm sited $20 \mathrm{~km}$ far from Khodabandeh city with 36,03 longitude \&49,22 latitude during the crop year 2014-15. Treatments plots include 3 levels of Humic acid (0, 2, 4 \& Liters per hectare) as foliar application after weeding bush and super Nitro plus in 3 levels (0, 2, 4 Liters per hectare) as tuber impregnating with manure solution has been done. Super Nitro plus manure include Bacillus subtilis, Pseudomonas, fluorescens and Azospirillum spp. This biologic manure contains bacteria per milliliter. In each treatment plot, 5 plants row with 75 centimeter distance and bushes with 20 centimeter distance have been determined. Planting has been done on May 20 and combating to weeds has been done manually. Tubers have been harvested at the end of September and tuber 
length features, yield per plant , shoot dry weight, average yield,tuber dry matter percent and crude protein percent as well as auxin hormone has been measured. Shenji et.al., ${ }^{25}$ method has been used to isolate auxin hormone. To determine auxin hormone density has been used of HPLC tool model Unican. Obtained data by MS tat-c program have been evaluated.

\section{RESULTSAND DISCUSSION}

Investigating effect of humic acid on tuber length, yield per plant, total dry weight of shoot, average yield, dry matter percent and crude protein percent has become significant in $(\mathrm{P}<0.01)$. The highest average yield per plant has been obtained from 4 (L) humic acid treatment with value of 578.3(g) and has been placed in first statistical group. Also, the highest average yield has been obtained from 4 (L) humic acid treatment with value of 31120 (kg/ha). The least average yield has been obtained from control treatment with value of 25960 ( $\mathrm{kg} / \mathrm{ha}$ ). Investigating effect of humic acid on dry matter percent has become significant in $(\mathrm{P}<0.01)$. The total dry weight of shoot has been obtained from 4 (L) with value of 88.46 (g). The dry matrer percent has been obtained from 4 (L) humic acid treatment. It seems that humic acid consumption cause to increment in absorption plant needed elements which it will increase tuber dry matter. (9) have investigated effect of humic acid on a kind of Triticum durum Salihli. Their results have indicated that humic acid cause to increment in absorption of Phosphorus, Potassium, Magnesium, Sodium, Copper and Zinc. Usage of humic acid in the form of foliar application and soil in plant will cause to increment in Auxin, Cytokinin and Gibberllins hormones in plant (10). Humic acid causes to increment in plant photosynthesis activity through increment in rubisco enzyme activity (26) (Table $1)$.

Effect of humic acid on cride protein percent has become significant in $(\mathrm{P}<0.01)$. highest and its value is related to $4(\mathrm{~L})$ humic acid treatment with value of 8.18 (\%) which has been placed at the same statistical group with $2(\mathrm{~L})$ treatment with value of 8.09(\%).Effect of humic acid on auxin hormone has become significant in $(\mathrm{P}<0.01)$. The highest value of this hormone has been obtained from 2 (L) humic acid treatment with value of 285.7
( $\mu \mathrm{mol} / \mathrm{g}$ ) which has been placed at the same statistical group with 2 (L) treatment with value of 282.3( $\mu \mathrm{mol} / \mathrm{g}$ ) (Table 1$)$.

Effect of Super Nitro plus (SNP) hasn't become significant on tuber length and yield per plant. The highest tuber length has been obtained from 2 (L) (SNP) with value of $5.5(\mathrm{~cm})$ which has been placed at the same statistical group with 4 (L) (SNP) with value of $5.48(\mathrm{~cm})$.Effect of (SNP) treatment on average yield has become significant in $(\mathrm{P}<0.05)$. Results have indicated that the highest average yield has been obtained from 4 (L) (SNP) treatment which has been at the same statistical group with 2 (L) and control treatment with value of 29420, 28539 \& 28420 ( $\mathrm{kg} / \mathrm{ha}$ ) respectively. PGPRs can directly and indirectly affect on plant growth which this increment can be done for plant through different mechanisms such as ; nitrogen supplying for plant through N2 consolidation, producing growth motive materials like Auxin, Cytokinin and Gibberllins, creating biologic control against soil pathogens (27) and preventing Ethylene production , solving inorganic Phosphorus and mineralizing organic Phosphorus(28) as well as making accessible other nutrition for plant. (29). Also , there is numerous reports on effect of Azotobacter chroococcum and Azospirillum. brasilense strains on yield of different plants which indicate that these bacterium will cause to increment in nitrogen consolidation, increment in absorption of elements such as ; Phosphorus, Potassium and Iron as well as plant water status improvement and production of Phytohormones in this plant (30)(Table 2).

Effects of (SNP) on total dry weight of shoot, dry matter percent and crude protein percent of tuber have become significant in $(\mathrm{P}<0.01)$. The total dry weight of shoot has been obtained from 4 (L) (SNP) treatment with value of 96.15(g). Also, the highest dry matter percent of tuber has been obtained from 4 (L) (SNP) treatment with value of 18.56(\%) which has been at the same statistical group with 2 (L) and control treatment with value of 18.37 and 18.25 (\%) respectively.the highest crude protein percent of tuber has been obtained from 4 (L) (SNP) treatment with value of 8.48(\%) has been placed in first statistical group. Single \& double inoculation of nitrogen consolidation bacteria and Phosphorous solving bacteria has significantly increased content of pea seed in 
comparison to control treatment and this increment has been equal to or more than $\mathrm{P}, \mathrm{N} \& \mathrm{NP}$ manure treatment ${ }^{31}$. Effect of (SNP) on auxin hormone has been significant in $(\mathrm{P}<0.01)$. The highest of this hormone has been obtained from 4 (L) (SNP) treatment with value of 303.4 ( $\mu \mathrm{mol} / \mathrm{g}$ ) which has been placed at the same statistical group with 2 (L) treatment with value of 300.4 ( $\mu \mathrm{mol} / \mathrm{g}$ ) (Table2).

Interaction of humic acid and (SNP) consumption on tuber length has become significant in $(\mathrm{P}<0.05)$. The highest tuber length has been obtained from 4 (L) humic acid treatment

Table 1. Means comparison for effects of humic acid levels on

different traits in potato (Solanum tuberosum var. marfona)

\begin{tabular}{|c|c|c|c|c|c|c|c|}
\hline $\begin{array}{l}\text { Humic acid } \\
\text { ( L/ha ) }\end{array}$ & $\begin{array}{l}\text { Tuber } \\
\text { length } \\
(\mathrm{cm})\end{array}$ & $\begin{array}{l}\text { Yield per } \\
\text { plant } \\
\text { (g ) }\end{array}$ & $\begin{array}{c}\text { average } \\
\text { yield } \\
\text { ( kg/ha ) }\end{array}$ & $\begin{array}{l}\text { Total dry } \\
\text { weight of } \\
\text { shoot ( g ) }\end{array}$ & $\begin{array}{c}\text { Tuber dry } \\
\text { matter } \\
\text { percent ( j ) }\end{array}$ & $\begin{array}{l}\text { Crude Protein } \\
\text { percent } \\
\text { ( j ) }\end{array}$ & $\begin{array}{c}\text { IAA } \\
(\mu \mathrm{mol} / \mathrm{g})\end{array}$ \\
\hline control & $4.97 \mathrm{~b}$ & 455.3 c & 25960 c & 82.77b & 17.67 c & $7.89 \mathrm{~b}$ & 266.9 b \\
\hline 2 & $5.53 \mathrm{a}$ & $495.7 \mathrm{~b}$ & $28150 \mathrm{~b}$ & 80.16 b & 18.43 b & 8.09 a & 285.7 a \\
\hline 4 & $5.73 \mathrm{a}$ & $578.3 \mathrm{a}$ & 31120 a & 88.46 a & $19.08 \mathrm{a}$ & 8.18 а & $282.3 \mathrm{a}$ \\
\hline duncan & $* *$ & $* *$ & $* *$ & $* *$ & $* *$ & $* *$ & $* *$ \\
\hline
\end{tabular}

Comparison with the Duncan test $(\mathrm{P}<0.05)$. ns: no significant $*$ and $* *$ : Significant at $5 \%$ and $1 \%$ levels.

Table 2. Means comparison for effects of super nitro plus levels on different traits in potato (Solanum tuberosum var. marfona)

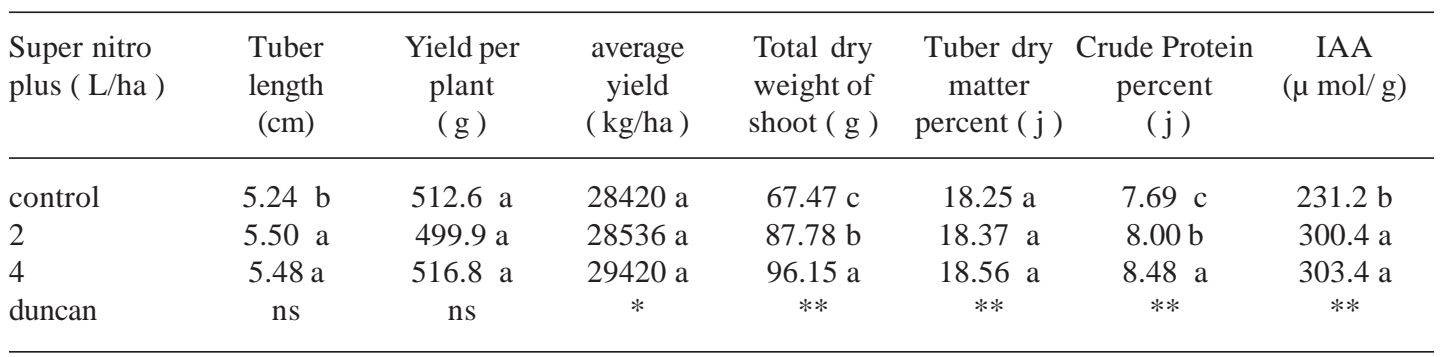

Comparison with the Duncan test $(\mathrm{P}<0.05)$. ns: no significant $*$ and $* *$ : Significant at $5 \%$ and $1 \%$ levels.

Table 3. Compared average to the interaction of Humic acid and super nitro plus on different traits in potato var.marfona

\begin{tabular}{lccccccc}
\hline $\begin{array}{l}\text { interaction of } \\
\text { Humic acid and } \\
\text { super nitro plus }\end{array}$ & $\begin{array}{c}\text { Tuber } \\
\text { length } \\
(\mathrm{cm})\end{array}$ & $\begin{array}{c}\text { Yield per } \\
\text { plant } \\
(\mathrm{g})\end{array}$ & $\begin{array}{c}\text { average } \\
\text { yield } \\
(\mathrm{kg} / \mathrm{ha})\end{array}$ & $\begin{array}{c}\text { Total dry } \\
\text { weight of } \\
\text { shoot }(\mathrm{g})\end{array}$ & $\begin{array}{c}\text { Tuber dry } \\
\text { matter } \\
\text { percent }(\mathrm{j})\end{array}$ & $\begin{array}{c}\text { Crude Protein } \\
\text { percent } \\
(\mathrm{j})\end{array}$ & $\begin{array}{c}\text { IAA } \\
(\mu \mathrm{mol} / \mathrm{g})\end{array}$ \\
\hline $0 * 0$ & $4.44 \mathrm{~d}$ & $411.1 \mathrm{c}$ & $25390 \mathrm{~d}$ & $63.94 \mathrm{f}$ & $16.94 \mathrm{~d}$ & $7.13 \mathrm{~g}$ & $223.3 \mathrm{~d}$ \\
$2 * 0$ & $5.28 \mathrm{bc}$ & $484.0 \mathrm{~b}$ & $26400 \mathrm{~cd}$ & $70.02 \mathrm{e}$ & $17.25 \mathrm{dc}$ & $8.09 \mathrm{~d}$ & $286.2 \mathrm{~b}$ \\
$4 * 0$ & $5.19 \mathrm{c}$ & $470.8 \mathrm{~b}$ & $26932 \mathrm{c}$ & $68.45 \mathrm{ef}$ & $17.83 \mathrm{c}$ & $7.84 \mathrm{ef}$ & $291.1 \mathrm{~b}$ \\
$0 * 2$ & $5.61 \mathrm{abc}$ & $498.7 \mathrm{~b}$ & $27265 \mathrm{bcd}$ & $87.43 \mathrm{c}$ & $18.67 \mathrm{abc}$ & $8.20 \mathrm{~cd}$ & $235.6 \mathrm{c}$ \\
$2 * 2$ & $5.48 \mathrm{abc}$ & $447.0 \mathrm{bc}$ & $27560 \mathrm{bcd}$ & $81.33 \mathrm{~d}$ & $18.12 \mathrm{bc}$ & $7.79 \mathrm{f}$ & $309.8 \mathrm{a}$ \\
$4 * 2$ & $5.49 \mathrm{abc}$ & $481.3 \mathrm{~b}$ & $26971 \mathrm{~cd}$ & $94.59 \mathrm{~b}$ & $18.50 \mathrm{abc}$ & $8.01 \mathrm{de}$ & $311.9 \mathrm{a}$ \\
$0 * 4$ & $5.68 \mathrm{ab}$ & $579.9 \mathrm{a}$ & $27340 \mathrm{bcd}$ & $89.14 \mathrm{c}$ & $18.75 \mathrm{ab}$ & $8.34 \mathrm{bc}$ & $234.7 \mathrm{c}$ \\
$2 * 4$ & $5.73 \mathrm{ab}$ & $568.7 \mathrm{a}$ & $25390 \mathrm{~b}$ & $96.95 \mathrm{~b}$ & $19.13 \mathrm{a}$ & $8.40 \mathrm{~b}$ & $305.1 \mathrm{a}$ \\
$4 * 4$ & $5.78 \mathrm{a}$ & $586.3 \mathrm{a}$ & $31740 \mathrm{a}$ & $102.3 \mathrm{a}$ & $19.36 \mathrm{a}$ & $8.70 \mathrm{a}$ & $307.2 \mathrm{a}$ \\
duncan & $*$ & $* *$ & $* *$ & $* *$ & $* *$ & $*$ & $\mathrm{~ns}$
\end{tabular}

Comparison with the Duncan test $(\mathrm{P}<0.05)$. ns: no significant $*$ and $* *$ : Significant at $5 \%$ and $1 \%$ levels. 
and 4 (L) (SNP) with value of $5.78(\mathrm{~cm})$. Interaction of humic acid and (SNP) consumption on yield per plant, yield average, total dry weight of shoot and dry matter percent has become significant in $(\mathrm{P}<0.01)$. The highest yield per plant has been obtained from 4 (L) humic acid and 4 (L) (SNP) with value of 586.3 (g) which has been placed at the same statistical group with 4 (L) humic acid and 2 (L) (SNP) and 4 (L) humic acid without bacteria with value of 567.8 and $579.9 \mathrm{~g}$, respectively. Also, the highest average yield has been obtained from 4 (L) humic acid treatment and 4 (L) (SNP) with value of $31740(\mathrm{~kg} / \mathrm{ha})$. The least average yield has been obtained from control treatment with value of 25390 (kg/ha) (Table 3).

The highest total dry weight of shoot has been obtained from 4 (L) humic acid treatment and 4 (L) (SNP) with value of 102.3 (g). The dry matrer percent of tuber has been obtained from 4 (L) humic acid treatment and 4 (L) (SNP) with value of 19.36(\%)which has been placed at the same statistical group with 4 (L) humic acid treatment and 2 (L) (SNP) with value of 19.13(\%). The highest crude protein percent has been obtained $4(\mathrm{~L})$ humic acid treatment and 4 (L) (SNP) with value of 8.70 (\%). Interaction of (SNP) and humic acid on auxin hormone has not been significant. The highest of this hormone has been obtained from 2 (L) humic acid treatment and 2 (L) (SNP) with value of 311.9 ( $\mu \mathrm{mol} / \mathrm{g}$ ) which has been placed at the same statistical group with 2 (L) humic acid treatment and 2 (L) (SNP), 4 (L) humic acid treatment and 2 (L) (SNP) and 4 (L) humic acid treatment and 4 (L) (SNP) with value of 309.8, 305.1 \& $307.4(\mu \mathrm{mol} / \mathrm{g})$, respectively. (Table3).

\section{CONCLUSION}

Considering people increment and need to more food as well as necessity of using healthier food, using alternative and less dangerous manures for individual and environment health is becoming more important and remarkable gradually. Therefore, using materials such as; humic acid and biologic manure can be a useful way to achieve to these objectives and producing healthier crops. In this research, it has been clarified that we can introduce alternative manures to prevent usage of chemical manures although we are force to use chemical manures due to soil weakness in terms of organic and nutrients.

\section{ACKNOWLEDGEMENTS}

Our thanks to the authorities of Paymannoor University for providing the financial support for performing this research project .

\section{REFERENCES}

1. Haase, T., C. Schuler, and J. Heb. The effects of different $\mathrm{N}$ and $\mathrm{K}$ sources on tuber nutrient uptake, total graded yield of potatoes (solanum tuberosum L.) for processing. Agron. J., 2007; 26: $187-193$

2. Islam, F., M. H. Rashid, M.A.Siddique, and M. R. Karim. Effect of seed size and spacing of seedling tubers from TPS on the grown and yield of potato. Bangla. Hort. 1993; 21: 25-30.

3. Rehman, F., S. K. Lee and H. Joung. Effects of various chemicals on carbohydrate content in potato microtubers after dormancy breaking. Asian J. Plant. Sci. 2002; 3: 224-225.

4. FAO ( 2005 ). FAO statical year book . food and agrieultural organization of the $U$ uited nation.

5. Doring, T.F., M. Brandt, J. Heb, M. R. Finckh, H. Saucke. Effects of straw much on soil nitrate dynamics,weeds, yield and soil nitrogen in organically grown potatoes. Sci. Direct. 2005; 94: 238-249.

6. Verlinden, G., T. Coussens, A. De Vliegher, and G. Baert. Effect of humic substances on nutrient uptake by herbage and on production and nutritive value of herbage from sown grass pastures. Grass and Forage Science. 2010; 65: 133-144.

7. Hakan ,C., A. Vahap Katkat, B. Bulent Asýk, and M.A Turan. Effect of Foliar-Applied Humic Acid to Dry Weight and Mineral Nutrient Uptake of Maize under Calcareous Soil Conditions Communications. Soil Science and Plant Analysis, 2011; 42(1): 29 - 38.

8. Tahir, M.M., M. Khurshid, M.Z. Khan, M.K. Abbasi, and H.M. Kazmi. lignite-derived humic acid effect on growth of wheat plants in different soils. Pedosphere. 2011; 21: 124-131.

9. Bulent Asik, B., A. Turan, H. Celik, and A. Vahap Katkat. Effects of Humic Substances on Plant Growth and Mineral Nutrients Uptake of Wheat (Triticum durum cv. Salihli) Under Conditions of Salinity. Asian Journal of Crop Science. 2009; 1: 87-95.

10. Abdel-Mawgoud, A. M. R., N. H. M. El- 
Greadly., Y. I. Helmy and S. M. Singer. Responses of tomato plants to different rates of humic based Fertilizer and NPK Fertilization. Journal of Applied Sciences Research. 2007; 3(2): 169-174.

11. Cordeiro F, Catarina C, Silveira V, Souza S. Humic acid effect on catalase activity and the generation of reactive oxygen species in corn (Zea mays), Bioscience, Biotechnology, and Biochemistry, 2011; 75: 70-74.

12. Abou-Aly, H.E. and M.A. Mady. Complemented effect of humic acid and biofertilizers on wheat (Triticumaestivum L.) productivity. Annals of Agric. Sci., Moshtohor, 2009; 47(1) :1-12.

13. Kloeper J.W., Scher. F.M., Laliberte, M. and Tipping, B. Emergence Promoting rhizobacteria:In Swinburne T.R. (eds). Description and Plant Diseases, Pelnum Publishing Company, New York, 1986; pp: 155164.

14. Nezarat, S., and A. Gholami. The effect of coinoculathon of Azospirillum and Psedomonas rhizobacteria on nutrient of maize (Zea mays L.). Journal Agronomy. 2009; 1 (1): 25- 32.

15. Piao, Z., Z. Cui, B. Yin, J. Hu. C. Zhou, G. Xie, B. Su, and S. Yin. Change in acetylene reduction activities and effects of inoculated rhizosphere nitrogen-fixing bacteria on rice. Biol. Fertil. Soils. No, 2005; 41: 371-378.

16. Vessey,J.K. plant growth promoting rhizobacteria as biofertilizers. Plant soil, 2003; 255: 571-586.

17. Chen, Y.P.,Rekha, P D., Aran, A.B., Shen, F.T., Lai, WA.AndC.C.Young. Phosphate olublizing abilites.department of soil and Environmental Sciences National chung Hsing University 2005.

18. Rajendran,k, and p.Devaraj. Biomass and nutrient distribution and their return of casuarina equiseti folia inoculated with bio fertilizers in farm land. Biomass and Bioenergy. 2004; 26 : 235-249.

19. Wu,S.C, Z.H.Caob, Z.G.Lib. K.C.Cheunga and M.H.wong. Effects of biofertilizer containing $\mathrm{N}$-fixer, $\mathrm{P}$ and $\mathrm{K}$ solubilizers and AM fungi on maize growth: a green house trial. Geoderma. 2005; 125:155-166.

20. Rodrigues, E. P., Santos Rodrigues, L., Martinez de Oliveira, A. L., Baldani, V. L. D., Teixeira, K.,Urquiaga, S. \& Reis, V. M. Azospirillum amazonense inoculation: Effects on growth, yield and N2 fixation of rice (Oryza sativa L.). Plant and Soil, 2008; 302, 249-261.

21. Cohen, A. C., R. Bottini, p. N. Piccoli. Azospirillum brasilense Sp 245 produces ABA in chemically-defined culture medium and increases ABA content in Arabidopsis plants. Plant Growth Regulation. 2008; 45: 97-103.

22. Bent, E., Tuzum, S., Chanway, C. P. and S. Enebak. Alterations in Plant growth and root hormone levels of lodgepole pines inoculated with rhizobacteria. Can. J. Microbiol. 2001; 47: 793-800

23. Patten, C. and B. R. Glick. Role of Pseudomonas putida Indole acetic Acid in Development of the Host plant Root System. Appl. Environ. Microbiol, 2002; 3795-3801.

24. Raja.P, S. Uma, H. Gopal and K. Govindarajan. Impact of Bio Inoculants Consortium on Rice Root Exudates, Biological Nitrogen Fixation and Plant Growth. Journal of Biological Sciences, 2006; 6 (5): 815-823 .

25. Shengjie ,H., Z.Jiang and D.Mingyu. Simulaneous determination of gibberelic acid,Indol-3-acetic acid and abscisic acid in wheat extract by solid-phase extraction and liquid chromatography-Talonta, 2008; 76:798-802.

26. Delfine, S., Tognetti, R., Desiderio, E., Alvino, A., Effect of foliar application of $\mathrm{N}$ and humic acids on growth and yield of durum wheat. Agron. Sustain. 2005; 25: 183-191.

27. Piromyou, P., B. Buranabanyat., P. Tantasawat, P. Tittabutr, N. Boonkerd and N. Teaumroong. Effect of plant growth promoting rhizobacteria (PGPR) inoculation on microbial community structure in rhizosphere of forage corn cultivated in Thailand. European Journal of Soil Biology, 2011; 47: 44-54.

28. Esitken, A., H. E. Yildiz, S. Ercisli, M. Figen Donmez, M. Turan, A.Gunes. Effects of plant growth promoting bacteria (PGPB) on yield, growth and nutrient contents of organically grown strawberry. Scientia Horticulturae, 2010; 124: 62-66.

29. Mayer, J., S. Scheid, F. Widmer, A. Fliebbach and H. R. Oberholzer. How effective are 'Effective micro organisms (EM)'? Results from a field study in temperate climate. Applied Soil Ecology, 2010; 46: 230-239.

30. Yasari, E., M. A. Esmaeili Azadgoleh, S. Mozafari and M. Rafati Alashti. Enhancement of Growth and Nutrient Uptake of Rapeseed (Brassica napus L.) by Applying Mineral Nutrients and Biofertilizers. Pakistan Journal of Biological Sciences, 2009; 12: 127-133.

31. Elkoca E, Kantar F and Sahin F, Influence of nitrogen fixing and phosphorus solubilizing bacteria on the nodulation, plant growth, and yield of chickpea. J Plant Nutr, 2008; 31: 157171 